\title{
In gratitude for grace: praise, worship and the sanctified life*
}

\author{
Tom Greggs, University of Aberdeen
}

t.greggs@abdn.ac.uk

\begin{abstract}
This article seeks to offer a theological account of gratitude from a Protestant perspective. It argues that the Christian life is one marked by a covenant of grace and gratitude in which the human creature responds to the superabundant merciful grace of God in thanksgiving, and in so doing participates in the merciful grace offered to the creature by God: in other words, the response of gratitude is a participating in the grace offered by God, and as such is a full recognition of the ways of grace which flow from the divine life to creation. The first section of this article examines this theme in relation to creation from nothing through which is established the creator-creature distinction which marks the foundation for recognising all of God's ways with the world as gracious, and determines that the appropriate reply of the creature to that grace is to receive it in thankfulness. The second section of the paper seeks to establish God's electing will as the foundation for and presupposition of creation in terms of God's willing to be for another outwith His own being: in this turning to another is the superabundant overflow of divine love which is the basis of grace. The creature, as the one elected, replies in gratitude as she too is caught up in God's gracious moving towards another. The third section examines justification by grace as the soteriological form of God's gracious turning towards the creature in divine mercy; this section seeks to establish gratitude not as a condition for the reception of divine grace, but grace as that to which gratitude is a reply and in which gratitude comes to be the way in which creation shares in God's covenant with the creature. The fourth section sketches the forms of gratitude that one might find in the Christian life, pointing to penitence, Christian obedience and praise in song; these are brought together in the signification of the covenant in the sacraments of baptism and the eucharist.
\end{abstract}

Key terms: gratitude; grace; creation; election; obedience; sacraments

\footnotetext{
* This paper was first given at Blackfriars, Oxford University, at the Jubilee Centre Conference on Gratitude. The paper was commissioned as an exploration from a Protestant perspective of the concept of gratitude. Quiet engagement with the theology of Karl Barth occurs throughout the article, largely in the footnotes, as Barth's theo-logic is drawn upon constructively for a theology of gratitude. For a broader consideration of gratitude in the Christian tradition, especially in reference to the wider context of the intellectual history of gratitude, see Peter J. Leithart, Gratitude: An Intellectual History (Waco: Baylor University Press, 2014).
} 
The Christian life is one marked by a covenant of grace and gratitude in which the human creature responds to the superabundant merciful grace of God in thanksgiving, and in so doing participates in the merciful grace offered to the creature by God: in other words, the response of gratitude is a participating in the grace offered by God, and as such is a full recognition of the ways of grace which flow from the divine life to creation. We see this inter-relation of grace and gratitude in creation, election and justification; and the concrete forms of thanksgiving in the Christian life are repentance, praise in song, and obedience, with the covenant of these concrete forms signified in the sacraments.

Grace and gratitude are innately but asymmetrically conjoined. Gratitude does not involve any equal or required response to grace; grace does not depend on gratitude. However, arising from the same Latin root, grace and thanks are both related: gratia offering the potential meaning of both grace and thankfulness. But the response of gratitude is neither a necessary one nor one on which the grace (so as to be grace) is contingent. Instead, both grace and gratitude involve non-necessary abundance and overflow. ${ }^{1}$ As the Irish poet, Micheal O’Siadhail has it in his poem Gracias:

Spanish like Latin grazie

From the Latin we know in 'grace'

And 'gratitude', which in term displays

A deeper root that meant 'to praise

Aloud' that shows again in 'bard',

'The one who lauds', 'praise-giver'.

\footnotetext{
${ }^{1}$ This is a very different condition of human life to that described by Gordon Mikoski: Mikoski identifies the culture in which we live as one of 'deficit, demand and desire' brought about by a deep-set ingratitude in society (Gordon Mikoski, 'On Gratitude,' Theology Today 61, no.4 (2011), 387). A theological consideration of gratitude in light of this seems pressing, especially if Immanuel Kant is correct in seeing ingratitude as one of the three worst vices that can affect the individual and society (Immanuel Kant, Lectures on Ethics, eds Peter Heath and J. B. Schneewind (Cambridge: CUP, 1997), 197). Despite this, gratitude is a theme which is relatively neglected in much recent theological discourse.
} 
And so I hand it to you. I deliver

My tribute, less quid pro quo

Than overflow. Well good for you! $!^{2}$

'[L]ess quid pro quo / Than overflow', gratitude is part of an overflow in which a free and open response is caught up in the movement of grace which is itself an overflow of the free and open kindness of God. From grace comes a free response to grace - not to condition grace into its gracious nature, but to recognize it as grace and to replicate its form in a free and overflowing reply which catches itself up in the divine way of grace. ${ }^{3}$

The first section of this article will examine this theme in relation to creation from nothing through which is established the creator-creature distinction which marks the foundation for recognising all of God's ways with the world as gracious, and determines that the appropriate reply of the creature to that grace is to receive it in thankfulness. The second section of the paper seeks to establish God's electing will as the foundation for and presupposition of creation in terms of God's willing to be for another outwith His own being: in this turning to another is the superabundant overflow of divine love which is the basis of grace. Again, the creature, as the one elected, replies in gratitude as she too is caught up in God's gracious moving towards another. The third section examines justification by grace as the soteriological form of God's gracious turning towards the creature in divine mercy. This section seeks to establish gratitude not as a condition for the reception of divine grace, but grace as that to which gratitude is a reply and in which gratitude comes to be the way in which creation shares in God's covenant with the creature. The fourth section seeks to sketch the forms of gratitude that one might find in the Christian life, pointing to penitence,

Christian obedience and praise in song; these are brought together in the signification of the covenant in the sacraments of baptism and the eucharist.

\section{Creator-creature Distinction: creation exists out of sheer grace}

The foundation for human gratitude can be found in the fitting response to the sheer grace of the Creator in the event of creation. This is a principle St Paul establishes in Ephesians 5:20,

\footnotetext{
${ }^{2}$ Micheal O’Siadhail, Collected Poems (Chester Springs, Pa.: Bloodaxe Books, 2014), 687. Permission granted by author.

${ }^{3}$ This conceptualisation of gratitude differs somewhat from a more Thomistic approach. For Thomas, gratitude is an annexed virtue (on annexed virtues, see $S T$ II.2, q.80) to the virtue of justice (as are piety, religion and obedience: ST II.2, q.58). Thomas' account is very much concerned not with overflow but with debt, which is responded to in a hierarchy of worship (in different forms dependent on the one to whom the gratitude is shown - God (through religion); parents (through honour); and superiors (through observance)). Obligation is a major theme here. See ST II.2, q.106 (and q.107 for the shadow vice of ingratitude).
} 
where he asserts that the believer should give 'thanks always for all things to God and the Father in the name of our Lord Jesus Christ'. To give thanks always for all things is an attitude that stems from a sense of the utter dependence of creation for its existence upon the Creator without whom there would be nothing. Creation comes into being out of nothing from the hand of the Creator, who does not create for His own benefit or gain, but in sheer and measureless freedom and grace. Creation is, furthermore, sustained from its return to nothing at every moment by its dependence upon the preserving presence of God who in absolute grace holds all creation in its being. To such an act of grace, the only fitting response of the creature is that of thankfulness to the Father for the life that the creature enjoys. ${ }^{4}$

Such responsive gratitude is not, however, a response which affects the divine life, since were gratitude to add anything to God, creation would not be an act of sheer and measureless grace, and the gratitude offered in return for that grace would be diminished by virtue of its benefits to and effects on the Creator. Rather, just as grace is God's outward activity in and towards creation; so too gratitude is the creature's outward activity in response to and towards God. In this, we see the proper relationship between God and God's creation: the unending movement of free grace from God replied to by the creature in gratitude; the movement of God towards creation is grace, and the responsive movement of the creature towards God in gratitude and thankfulness for grace.

This relationship does not stem from any component within creation natural to it. There is no analogia entis in a divine likeness of the creature such that the response of gratitude to grace is somehow natural or innate to creation even in its fallen state: ${ }^{5}$ creation, in other words, does not naturally recognise itself as creation, and is not naturally ordered in a fallen state to give thanks for the grace of its Creator in creating the world. There is no prior creaturely possibility of gratitude to the moment of recognising in faith that the world depends on the

\footnotetext{
${ }^{4}$ Cf. David F. Kelsey, Eccentric Existence: A Theological Anthropology (Louisville: Westminster John Knox, 2009), 344: '[D]oxology is the appropriate response to God's glory in Godself, or more exactly, the appropriate response to the hospitable generosity of the triune God's glory in se ... [G]ratitude, precisely as doxological gratitude, is appropriate response to God for the glory of God expressed in our proximate contexts. It is thanks for those proximate contexts, including fellow human creatures whose practices in large part constitute them, as expressive of God's glory and thus as themselves derivatively the glory of God.'

${ }^{5}$ For an over-view of issues relating to the analogia entis, see Thomas J. White (ed.), The analogy of being: invention of the Antichrist or the wisdom of God? (Grand Rapids: Eerdmans, 2011). Dietrich Bonhoeffer's discussion of related themes to the post-lapsarian condition can be found in his Act and Being: Transcendental Philosophy and Ontology in Systematic Theology, DBWE vol. 2 (Minneapolis, Fortress, 2009), 136-55; although gratitude is not mentioned directly here, the force of the argument is retained since the Lutheran principle of sola fide credendum est nos esse peccatores applies.
} 
grace of its Creator for its existence and preservation. ${ }^{6}$ The recognition of the goodness of creation stems from its being consecrated as such by the Word of God and in prayerfulness. As 1 Timothy 4:4-5 has it: 'For everything God created is good, and nothing is to be rejected if it is received with thanksgiving, because it is consecrated by the word of God and prayer.' The recognition of creation's goodness, and thereby of the grace of the Creator in creating, arises from the faith which is placed in the Word of God which testifies that creation comes from the hand of the Creator. As Karl Barth suggests, we should point not to an analogy of being but to an analogy of faith - the likeness of the known in the knowing, and not the likeness of the being of the Creator in being of the created. The possibility of gratitude flows from the knowability of the Creator whom God's Word reveals and who is known by an act of the Holy Spirit in the event of faith. ${ }^{7}$ Gratitude is not a natural condition for the creature, but one which comes only in recognition by the creature of the creature's creatureliness - that is, the creature is one created and dependent upon the Creator, who creates not for His own benefit but out of measureless grace.

Once, however, this reality is acknowledged by the creature, the only possible response is one of gratitude and the offering of thanksgiving which is evoked by the object towards which the gratitude is directed. ${ }^{8}$ In this way, the offering of our thanks can consist only in a joyful acknowledgment of God's Self-revelation as Creator. ${ }^{9}$ It is not, therefore, natural to creation to give thanks to God. Instead, as God is received and recognised by the creature as Creator through God's gracious self-revelation, the creature is caught up in the grace of God, and replies to such grace analogously in gratitude and thanksgiving. It is, therefore, a gift of God's grace in revelation for the creature to be able to recognise God's graciousness as Creator. To be permitted to thank God is a gift and permission of God. ${ }^{10}$ Such permission and the possibility to thank God in gratitude for His grace does not belong properly to the creature qua fallen creature. It is, instead, something the creature is permitted to do by God's graciousness: it is a gift of God to recognise God's ways in creation as gift; and that the

\footnotetext{
${ }^{6}$ Karl Barth, Church Dogmatics (London: T\&T Clark, 2004), I/1, 41. [Henceforth, Church Dogmatics will be referred to as CD followed by volume and part.]

${ }^{7}$ Ibid., 243-4. Further consideration is required here of the doctrine of the imago dei. It is worth noting that for Calvin, to glorify God by praise and gratitude is what it means to image God as we were created to do so; see John Calvin, Institutes of the Christian Religion, ed. John T. McNeill \& trans. Ford Lewis Battles (Louisville: Westminster John Knox, 1960), I.15.3 (186-9); cf. Brian A. Gerrish, The Old Protestantism and the New: Essays on the Reformation Heritage (Chicago: University of Chicago Press, 1982), 154.

${ }^{8} \mathrm{CD}$ II $/ 1,216$.

${ }^{9}$ Ibid., 217.

${ }^{10}$ Ibid., 670.
} 
possibility of gratitude and thanksgiving comes from God. ${ }^{11}$ Gratitude is a gift from God because there is no quid pro quo in divine-creaturely relationality: gratitude from the creature adds nothing to God; the doctrine of creatio ex nihilo assures us of that. There is an infinite qualitative difference between God and the creature such that nothing in God can be contingent on the creature's actions. God's own superabundant life is so superabundant that it both requires nothing of the creature to perfect its own perfectly complete being, and at the same time is able to allow the creature to receive as gift the revelation of God's own gracious and superabundant life. God is not bound to allowing us to respond to Him in gratitude, but enables us to share in His glory by recognising His grace as gift, ${ }^{12}$ establishing an asymmetric relationship between Himself and His creature in which the creature is enabled to recognise the Creator as such. ${ }^{13}$ In this way, we may say that the creature is enabled to share in the perfection of grace that is the life of God. This does not add anything to God, but enables the creature to share in a perfection which is already perfect and realises itself as evermore perfect as the creature is by an act of grace enabled to share in the perfection of grace by responding in free gratitude, and perfecting an already perfect and completing and already complete superabundant and free gracious life in God. ${ }^{14}$ As Daniel Hardy and David Ford put it:

There is no law of praise, and perfection would not be perfect if it had to require praise for its completion. Yet the odd fact is that in this way perfection itself can be perfected, and the more perfect it is the more wonderfully it evokes new forms of perfection. The logic is that of overflow, of freedom, of generosity. ...

Thanks is the companion of praise, and shares the same strange logic. Just as praise perfects perfection, so thanks completes the completed. ... The greater and more decisively complete the event, the more thanks are appropriate. ${ }^{15}$

As a completely free act of God's grace, creation is graced with the possibility of recognising itself through the revelation of God as an act of God's good grace. As such, it is freed to give

\footnotetext{
${ }^{11}$ Ibid., 671.

${ }^{12}$ Cf. CD II/1, 671-2.

${ }^{13}$ Clearly there are lots of ways to read creation: the problem of evil makes this clear, as does biological materialism which recognises nature as red in tooth and claw. There are, furthermore, other possible relations 'gods' can have to creation - as contingent upon the acts of creation. In this way we might read the struggle against Baal and other fertility gods in the Old Testament.

${ }^{14}$ David F. Ford and Daniel W. Hardy, Living in Praise: Worshipping and Knowing God, Second Revised Edition (Grand Rapid: Baker Academic, 2005), 8-10.

15 Ibid., 9-10.
} 
free thanksgiving, which does not add to God and is not a necessary response but is one which is fitting and appropriate as creation is caught up in God's ways of grace.

\section{Caught up in God's movement: living thankfully in election}

These ways of grace do not necessarily begin in the divine decree of creation. Creation is itself an outworking (the external basis for the covenant of God whose internal basis is the grace of the divine life) of God's covenant which is the internal basis of His of His external ways. ${ }^{16}$ It is worth here quoting Karl Barth at length:

... the covenant is the internal basis of creation. It is certainly not its external basis. Its external basis is the wisdom and omnipotence of God, who is sure of Himself as Creator because He is God, who at the creation of the world and [hu]man[ity], at the laying of the presupposition of the covenant, at the preparation of the creature for His grace, is never at a loss for the right ways and means, but whose Word is sufficient to give being and existence to the creature as the object of His love and as the partner of His covenant. But creation also has ... its internal basis. This consists in the fact that the wisdom and omnipotence of God the Creator was not just any wisdom and omnipotence but that of His free love. Hence what God has created was not just any reality ... but that which is intrinsically determined as the exponent of His glory and for the corresponding service. What God created when He created the world and [hu]man[ity] was not just any place, but that which was foreordained for the establishment and the history of the covenant, nor just any subject, but that which was to become God's partner in this history, i.e., the nature which God in His grace willed to address and accept and the [hu]man predestined for His service. ${ }^{17}$

In this, there is an important order. While creation might take formal and historical precedence over election and covenant, election (and covenant) takes material and substantial precedence. ${ }^{18}$ The presupposition and purpose of creation is election. Because of this, we can join with Paul in saying: 'In every thing give thanks: for this is the will of God in Christ Jesus concerning you' (I Thess. 5:18). God has predestined that He will reconcile and redeem, and for this purpose He creates: creation, reconciliation and redemption are all moments of God's electing purpose and will — of God's will and self-determination to be for another beyond

\footnotetext{
${ }^{16} \mathrm{CD}$ III/ $1, \S 41.2-3$.

17 Ibid., 231.

18 Ibid., 232.
} 
His internal triune life as Father, Son and Holy Spirit. Gratitude for creation is, therefore, more fundamentally gratitude for God's electing will to be for the creature - a will which precedes creation to allow creation to exist for the purpose of reconciling and redeeming the creature.

Thus, the Christian life is one characterised by the service and blessedness of the elect, which involves living in the recognition and realization of the electing will of God, of God's gracious Self-determination to be for another outside of His own eternal triune life. The Christian life consists in this of gratitude for the Self-giving of God in His electing grace. The Christian is chosen by God so that there might be gratitude in her life for God's electing purpose; for God's foreordination of the covenant He establishes in Jesus Christ for which purpose God creates. ${ }^{19}$ Gratitude corresponds to the kindness of God in His free electing grace, in God's election of humanity, in His Self-determination to be Jesus Christ. But this life of gratitude is not simply one of response; it is, instead, one of participation in the overflowing superabundant life of God. ${ }^{20}$ Since gratitude is a mode of response to the kindness and grace of God's electing will, which cannot be altered, repeated or returned, gratitude shares in the very overflowing nature of that gracious movement of God in election. Gratitude seeks to respond to the grace of election by corresponding to that election - that free grace which flows from the Creator to the creature - and seeking to reflect it. Gratitude, if we like, is about being caught up in the movement of God's election, which is not simply a decree but the movement and orientation of the divine life in its superabundant overflow to that which is outside of it. To quote Karl Barth once more: 'what is meant by gratitude, and therefore blessedness, and therefore being loved by God? Clearly, participation in the life of God in a human existence and action in which there is a representation and illustration of the glory of God Himself and its work. ${ }^{21}$

Gratitude is, therefore, not simply about the Christian's own determination in relation to the electing will of God, but about the elect's being caught up in God's way with the world for the purpose of witness and testimony to all creation of God's way with creatures so that they

\footnotetext{
${ }^{19}$ For Karl Barth, election is the election of Jesus Christ; and in Jesus Christ, all humanity is elected. See CD II/2, especially paragraph 33. Much has been written on this, and for surveys of the literature and recent discussions of the topic, the reader is directed to my Barth, Origen, and Universal Salvation: Restoring Particularity (Oxford: OUP, 2009), chapter 2; and my Theology against Religion: Constructive Dialogues with Bonhoeffer and Barth (London: T\&T Clark, 2011), chapter 5.

${ }^{20} \mathrm{CD} \mathrm{II} / 2,413$.

${ }^{21}$ Ibid., 413. On the topic of the relationship between election and the human life, see Paul T. Nimmo, Being in Action: The Theological Shape of Barth's Ethical Vision (London: T\&T Clark, 2011).
} 
too can share in this blessedness and gratitude. The Christian is caught up in the movement of election, in God's gracious willing to be for another, through gratitude and by this is determined to witness to the electing will of God in Jesus Christ - a will that we see in creation, reconciliation and redemption. Again, this is not simply a response to God, but a participation in God's gracious good pleasure for creation. In this way, election is not only achieved for the creature but in the creature, who participates in gratitude and witness in the divine way with the world. The elect is one who through gratitude for God's way stands in the service and commission of God, as she is summoned to this by the Holy Spirit, and who witnesses to humanity's participation in election as the beginning of all of God's ways and works. ${ }^{22}$ In this way, the elect through her gratitude becomes a messenger of God to represent and portray the glory of God as one sent to be an apostle of grace through the witness she offers to that work of grace by which she is elected. ${ }^{23}$

But what is the means by which the creature comes to participate through gratitude in this electing will of God? For the Protestant traditions, this cannot be through her own works or the efficacy of her ritual. No; the human creature comes to share in this election by grace alone.

\section{Justification by grace alone: no works only gratitude for divine mercy}

As the Psalmist reminds us, we are to give thanks to God because of his enduring love: 'Praise the LORD. Give thanks to the LORD, for he is good; his love endures forever' (Psalm 106:1). The love of God is enacted towards the creature in God's grace and mercy. Mercy points us to the very centre of divine love and its specific determination as grace: God's movement towards the creature (His superabundant life outside of Himself) need not necessarily be merciful. However, God's grace takes place in the presupposition that creature is in distress and in this God wishes to grant her assistance in her fallenness and sin. Thus we can see that mercy and grace are inter-related: mercy is included in grace, and grace itself has a form which is itself merciful. ${ }^{24}$ The concrete form of God's love is that of mercy: God loves humanity in a merciful way. Mercy is the '... disposition of the heart of the being of God.'25 It is this which characterises the relationship of God to creatures because God is love, and this love is actualised in the concrete of gracious and merciful loving of fallen creation. This

\footnotetext{
${ }^{22} \mathrm{CD} \mathrm{II} / 2,414$.

${ }^{23}$ Ibid., 415 . Clearly, there is a distinction between electing God and elected man. Elected man has no place to choose or reject others.

${ }^{24}$ Ibid., 369.

${ }^{25}$ Ibid., 375.
} 
grace and mercy is entirely unearned, and cannot be conditioned by the creature: ${ }^{26}$ it is not itself responsive to human gratitude; instead, it is responded to in human gratitude. This is the heart of the Protestant doctrine of justification by grace alone - sola gratia. Salvation stems only from God, and human actions do not condition God into expressions of His love in grace and mercy. ${ }^{27}$ Such grace is freely given by God and has the form of mercy in its relation to the fallen creature. Only the grace of God can save, and the life of faith is a life which responds, and in this response participates in the movement of God's grace towards the creature.

God is love; God's loving is gracious in its overflow to creation; and that grace is itself merciful in its concrete form in relation to the fallen creature. God's engagement with the world stems from His unchanging being which is love and in which He is gracious in His mercy and merciful in His grace. Divine mercy does not stem from the works of the creature in obedience or religious rites, but gathers up the creature in God's ways in which the creature offers thanks for mercies unearned and graces freely given. In another of Micheal O'Siadhail's poems on 'Thanks', he writes this on the French word Merci:

From Latin for 'hire' or 'fee'

Wage for services rendered

Drifts to 'favour' or 'mercy'.

No longer measure for measure

More a gift bestowed,

A giving at someone's pleasure.

One word to name and bless

A gratuitous merci,

Unearned openhandedness. ${ }^{28}$

Gratitude for salvation is a gratuitous thankfulness for what O'Siadhail calls ' $[\mathrm{u}]$ nearned openhandedness'. Gratitude is a mercy that stems from the unending divine mercy, therefore - a creaturely analogy of faith in divine grace to the divine mercy.

\footnotetext{
${ }^{26}$ See here the discussion of creatio ex nihilo above.

${ }^{27}$ I have explored this issue in relation to belief as a potential work in my work on universalism. See especially, 'Pessimistic Universalism: Rethinking the Wider Hope with Bonhoeffer and Barth,' Modern Theology 26, no. 4 (2010), 495-510; Barth, Origen, and Universal Salvation; and chapter five in Theology against Religion.

${ }^{28}$ O'Siadhail, Collected, 686.
} 
In offering gratitude to God for His grace and mercy, the human being becomes a covenant partner of God, receiving from God freely that which is freely given. The reception of that which is given is freely and not passively received: reception involves active gratitude. This gratitude is not a condition for that which is given, but an active participation in it. As Barth has it:

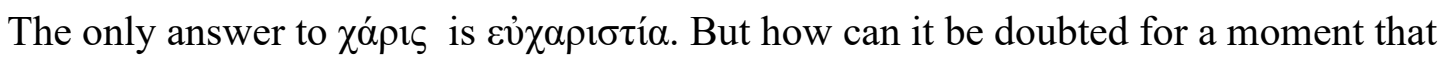

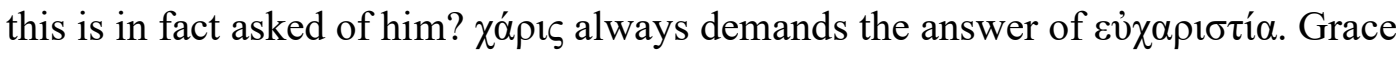
and gratitude belong together like heaven and earth. Grace evokes gratitude like the voice an echo. Gratitude follows grace like thunder lightning. Not by virtue of any necessity of the concepts as such. But we are speaking of the grace of the God who is God for man, and of the gratitude of man as his response to this grace. ${ }^{29}$

Gratitude is, therefore, the fitting and appropriate response to the declaration of God that $\mathrm{He}$ will be our God: it is the fulfilment of the second clause of II Cor. 6:16b: 'I will be their God, / and they shall be my people.' To be God's people means to respond to the God who is already our God in His merciful grace by living in gratitude to and for His gracious turning towards creation. This gratitude is something which only grace can achieve in us: it is only by the grace of God that we can recognise God's gracious activity in the world; grace is itself the only possibility of the responsive participation in grace, or else salvation would come from some other place than that of the divine merciful free-giving. Grace cannot be conditioned for its reception, but must remain gracious; and so, to perceive grace (and in so doing recognise and receive it) can only happen in grace. ${ }^{30}$ The essential completeness (the once and for allness) of salvation removes any possibility of a response that is not (even in its responding) a recognition of the all-sufficient nature of divine grace and mercy which is not increased or determined by the creaturely response of gratitude. ${ }^{31}$ Thanksgiving and praise are a gratuitous response to the divine life. Geoffrey Wainwright puts this elegantly: 'The gratuity of worship expresses the character of salvation as gift: a gift to be actively enjoyed. ${ }^{32}$ There is a virtous cycle that exists here: in thanking God for His grace, humans become ever more aware of what they are thankful for; in gratitude for grace, grace becomes more gracious and gratitude more thankful.

\footnotetext{
${ }^{29} \mathrm{CD}$ IV/1, 41.

${ }^{30}$ Ibid., 45.

${ }^{31}$ Cf. Ford and Hardy, Living in Praise, 105.

${ }^{32}$ Geoffrey Wainwright, Doxology: The Praise of God in Worship, Doctrine and Life A Systematic Theology (New York: Oxford University Press, 1980), 27.
} 
Thus, to claim that reception of grace and mercy in thankfulness is an activity of divine grace and mercy is not a straightforward removal of human free will: there is no relationship of competitiveness here. Rather, in this cycle of free grace and gratitude, one is enabled to see human agency in its right and proper place. As Ford and Hardy put the point:

The coming together of divine and human freedom of God is not experienced as a reduction of human responsibility; rather, the call to free self-giving is intensified and empowered, and praise [and, we may say, gratitude] is the experience of this, to which all the rest of life needs to be conformed. ${ }^{33}$

What then is the form of this life in response to the grace of God through which it participates in grace and gratitude? It is to this that the remainder of this article turns, in seeking to sketch four forms this life of gratitude for grace takes in the context of the praise and worship of the sanctified life.

\section{The Form of Gratitude for Grace}

Caught up in the movement of grace from God to that which is not God, gratitude takes four concrete forms in the Christian life. These forms listed are indicative from a longer list, but might be thought of as central aspects to the life of gratitude for the grace of God in creation, election and salvation.

\section{A. Humble Penitence arising from Gratitude}

Thanksgiving for grace determines that the disposition of the believer can never be anything other than that of humble penitence. Aware that nothing ever is earned or deserved from God (that nothing can condition God into mercy), the Christian lives in a life which seeks in gratitude to be open to the grace of the Lord in His merciful acts. No partial penitence or sense of earned response from action is possible on the part of the creature in relation to God. Recognising that the only response to God is that of gratitude for God's superabundance in grace determines that the primary act of the grateful sinner in expressing gratitude is to offer confession: gratitude engenders humility to God not entitlement; gratitude is most appropriately offered on bended knee to the Father who in His grace is merciful to His creation, catching them up in His movement towards them. ${ }^{34}$ The response of gratitude is one

\footnotetext{
${ }^{33}$ Ford and Hardy, Living in Praise, 13.

${ }^{34}$ This idea of 'catching them up in His movement' might be otherwise spoken of as 'abduction'. On abduction, see Daniel W. Hardy, Wording a Radiance: Parting Conversations on God and the Church (London: SCM,
} 
of thankfulness for forgiveness, a thankfulness which never assumes as a right right the mercy and grace which comes freely from the Father: mercy and grace depend instead on God's constancy in His grace and mercy, rather than any action of the human creature. The creature will never deserve God's mercy and grace (since they are perfectly merciful and gracious); the response of the creature will always be one which recognises and gives thanks for the joy of forgiveness in gratitude, humility and repentance. The response will be one which in its penitence and humility perfects the already perfect grace and mercy of God. As John Wesley puts it:

The Scriptures describe that joy in the Lord which accompanies the witness of his Spirit as an humble joy, a joy that abases to the dust; that makes a pardoned sinner cry out, 'I am vile! ...' And wherever lowliness is, there is patience, gentleness, longsuffering. There is a soft, yielding spirit, a mildness and sweetness, a tenderness of soul which words cannot express. But do these fruits attend that supposed testimony of the Spirit in a presumptuous man? Just the reverse. ${ }^{35}$

Each new day we are called to give thanks to God for his merciful grace and gracious mercy, and never to treat those free gifts of God to the creature as privileges or entitlements to be presumed, but only as gifts offered - constant not on the basis of the creature's worth or action but on the basis of God's constancy (or immutability, as more classical terminology might put it). To recognise the gifts of God as mercy and grace requires the creature to realise her unworthiness of them, to identify her inability to save herself or do anything other than fall upon God's good pleasure. In this is the call to penitence, and for penitence flows further gratitude for forgiveness. For Luther, indeed:

God receives none but those who are forsaken, restores health to none but those who are sick, gives sight to none but the blind, and life to one but the dead. He does not give saintliness to any but sinners, nor wisdom to any but fools. In short: He has mercy on none but the wretched and gives grace to none but those who are in disgrace. Therefore no arrogant saint, or just or wise man can be material for God, neither can he do the work of God, but he remains confined within his own work and

2010), 45-56 (esp. 49-56) \& 67-71; cf. Peter Ochs, Another Reformation: Postliberal Christianity and the Jews (Grand Rapids: Baker Academic, 2011), 192-4.

35 John Wesley, The Works of John Wesley Volume 1: Sermons I, ed. Albert C. Outler (Nashville: Abingdon Press, 1984), 280. 
makes of himself a fictitious, ostensible, false, and deceitful saint, that is, a hypocrite. ${ }^{36}$

Reliance on the grace of God, to which we respond in gratitude, leads to a recognition of our unworthiness, a confession of sin, and further thanksgiving for salvation and forgiveness. In penitence, a cycle of gratitude is created in which gratitude for grace creates ever more thankfulness for the constant and enduring merciful grace of God. As St Paul has it: 'All this is for your benefit, so that the grace that is reaching more and more people may cause thanksgiving to overflow to the glory of God' (2 Corinthians 4:15).

\section{B. Gratitude in Faithful Obedience}

Although good works and obedience can never be the condition by which the merciful grace of God is offered, good works and obedience are enabled (in being caught up in that grace) to be a response to the free gift and giving of God. ${ }^{37}$ They are counterpoints which do nothing other than join in the great glorious symphony of God's gracious acts within creation. As the Heidelberg Catechism, Question 1 asserts, honouring and thanking God involves being 'willing and ready from the heart to live henceforth unto Him'. This involves turning the heart from being turned in upon itself to being turned to obeying the greatest commandment in loving God and neighbour. If sin is (in Luther's terms) the cor incurvatum in se, obedience is the repentant heart turned out in obedience towards fulfilling the law of grace that comes from God. Gratitude to God is expressed in the repentant human seeking to turn not only from sin but towards God, seeking to express her thankfulness for God's merciful grace in living for God. Karl Barth states:

It is only by a heart's willingness and readiness to live unto Him that God can be honoured, thanked and served. ...

In this sense, then, the glorifying of God consists simply in the life-obedience of the creature which knows God. It has no alternative but to thank and praise God. And in this thanks and praise it has nothing else to offer God - nothing more and nothing less than itself. This self-offering can have no other meaning - no higher and no lower - than that its existence becomes a reflection of the perfection of the divine being. ... In the conformity with God into which it enters, with this self-offering, in

\footnotetext{
${ }^{36}$ Martin Luther, Luther's Works, vol. 14., eds Jaroslav Pelikan and Daniel E. Poellot, trans. Arnold Guebert, (St. Louis: Concordia Publishing House, 1958), 163.

${ }^{37}$ For Calvin, gratitude and love for the Father should lead Christians to devote themselves completely to obedience to God and to seeking to honour God in all things. See Ioannis Calvini Opera Selecta 1:76.
} 
accordance with God's call and its own knowledge of Him, it [the creature] may honour God and therefore acquire and have a share in God's own honour. In this sense the way and theatre of the glorification of God is neither more nor less than the total existence of the creature who knows God and offers Him his life-obedience. Nothing can be omitted from the gift, the task, and the new gift here revealed and actual as the purpose of its existence. ${ }^{38}$

Again, what we see here is a sharing in God's ways: obedience is a gift in which the creature in thankfulness is able to offer her life to God and in that share in God's own honour and reflect God's own perfect grace and self-giving. The heart turned towards God participates in gratitude in the turning of God towards creation. This is something for which the grace of God in salvation liberates the human who is otherwise turned in on herself in her sin. ${ }^{39}$

Along with the Westminster Shorter Catechism (1647-48), we might say that the chief end of humanity is 'to glorify God and to enjoy Him forever'. This glorification comes in thankful response to God's grace in which we come to be caught up in God's glory, reflecting its grace and overflowing superabundance (rather than our own efforts or works) in our obedience to Him as we are caught up in God's ways with us. Geoffrey Wainwright states it as follows: 'Believers may render God glory by a kind of reflexion, as they are changed into his likeness, "from glory into glory" (cf. 2 Corinthians 3:18). They glorify God as they grow in conformity with his character. ${ }^{40}$ Rendering thanks, honour and glory to God comes in seeking to be like Him, turning away from ourselves and towards Him, and reflecting His gracious outwardness (His desire for encounter) in lives ordered towards Him and our neighbour in faithful adherence to the command of Jesus. This is a point Daniel Hardy makes in his work on the foundation of cognition and ethics in worship:

In direct openness to ... divine dynamic order, there also occurs an ontological movement in those who recognize it, whose existence is totally orientated to that which is recognized, in a total alteration of affection which brings about a habit of life. In its purified form, this ontological recognition in praise, which incorporates a purified reorientation, in which the dynamics of human life - both individual and social - are focused in correspondence with that which is recognized in praise.

\footnotetext{
${ }^{38} \mathrm{CD} \mathrm{II} / 2,674-5$.

${ }^{39} \mathrm{Cf} . \mathrm{CD}$ IV/2, 496.

${ }^{40}$ Wainwright, Doxology, 17.
} 
Whatever is the dynamic order recognized in the divine is therefore realized in the arrangement of human relationships in and with the world. ${ }^{41}$

Openness to the divine life determines an openness to the divine order of merciful grace, and should result in obedience to God's ways in the creature. Such obedience is nothing other than being caught up in God's own dynamic order, through which the creature is turned away from herself and towards God, and through which she participates in God's own ways with the world. Thus, the words of Colossians 3:17 are proved a reality in the life of the Christian: 'And whatever you do in word or deed, do all in the name of the Lord Jesus, giving thanks to God and the Father by him.'

\section{The Superabdunant Song: Singing in Praise and Thankfulness}

The expression of this repentant, obedient gratitude is not one of sorrow at human failings, but one of joy - a joy that comes in celebrating the divine grace and mercy that creates, elects, and saves the creature. The response of the creature to God is not appropriately fear, trembling and a subservient grovelling gratitude because God is the particular God known in His grace and mercy: there is no god beside Him, no god who does not reach us in His grace and mercy. Thus, our response should, instead, be a response of gratitude in joyous praise with music and song. With the Psalmist, we should say: 'Let us come before him with thanksgiving and extol him with music and song. For the LORD is the great God, the great King above all gods' (Psalm 95:2-3). We join in the way of God with the world, in the way of mercy and grace; and in this is the assurance of joy which should lead to jubilation. One sign of gratitude for the grace of God (perhaps one which as a Methodist I might wish particularly to emphasise) should be song. The Christian life does not reply and is not caught up in divine grace in monotone satiety but in superabundant and jubilant thankfulness, which creates ever new possibilities of rhythm, harmony and variety. God's people are to sing unto the Lord a new (an ever new) song in the unending hymn of thankfulness and praise. Such singing is again a participatory response in the Christian life to the divine Self-giving. It is a joining together, a listening to one another, a seeking of harmonious life with one another and God, symbolised in singing together. Song is a sign of the harmony of our lives with God - an anticipatory eschatological joining with all creation, with the mountains and the hills that will clap their hands, and with the angels who by day and by night sing 'Holy, holy, holy is the

\footnotetext{
${ }^{41}$ Daniel W. Hardy, God's Ways with the World: Thinking and Practising Christian Faith (Edinburgh: T\&T Clark, 1996), 14.
} 
Lord God Almighty who was and is and is to come'. In song and singing, '[1] anguage itself is transcended and its delights and power are intensified, and at the same time those who join in are bound together more strongly. ${ }^{42}$ Singing both raises the singer and her thankfulness to a higher level (transposing her thankfulness by adding another dimension of possibility with unending possibilities of variation) while at the same time binding the singer to those others to whom she has to be attuned: it is an expressive variation of an orientation on God (joining in the unending hymn of praise in heaven) and on the other around us (singing in harmony and variation with those others in the congregation).

\section{Sacraments: No salvific effectiveness, only a covenantal gratitude for grace}

Finally, the Christian life is one of covenant in faithful obedience expressed in sacramental commitment and observation - the covenanting in baptism to the new life in Christ which is renewed in the constancy of receiving the eucharist. Sacraments are not effective of salvation, nor does any efficacy they possess arrive ex opera operato. Instead, they are external expressions of an inward reality.

Baptism in the Methodist tradition, for those who cannot respond for themselves, is a sign to be a reminder of the undeserved and all sufficient prevenient grace of God which exists before and is not conditional upon any response from the Christian. It is a reminder that the new life in Christ' is completely a gift from God, and God is not and cannot be conditioned by any human action into giving this gift. Infants are baptised because grace precedes all acts of gratitude or cognition, and gratitude rests on participative response to that grace, which involves first being caught up in it. Thus, the minister says to the candidate:

For you Jesus Christ came into the world;

for you he lived and showed God's love;

for you he suffered death on the Cross;

for you he triumphed over death, rising to newness of life;

for you he prays at God's right hand:

all this for you,

before you could know anything of it.

In your Baptism the word of Scripture is fulfilled:

'We love, because God first loved us.'

\footnotetext{
${ }^{42}$ Ford and Hardy, Living in Praise, 19.
} 
In the waters of baptism comes the gift of God's love symbolised in water's very everydayness, its essentialness for life. That water is essential for life is a reminder that all that is (creation itself) is a gift of the grace of God; that divine grace is more essential to life than water, and upon divine grace rests water's own life-giving existence. In baptism, we are reminded of God's covenant to us to be our God; of His provision of life and new life; and in the act of baptising, we remember that our response is not one of our own efforts or powers, but one of being caught up in God's ways of merciful grace with the world - responding by receiving and participating in the divine covenant with creation.

The eucharist is an act of continued thankfulness for this covenant of God's grace and mercy in Christ's body and blood to which humans respond in breaking bread and sharing wine as a memorial of thanksgiving for God's once and for all act. ${ }^{43}$ Grace and gratitude are in the Eucharist linguistically linked: we cannot fail to see the charis in eucharistia. ${ }^{44}$ In the elements of bread and wine, in their created ordinariness which sustains life through its provision of sustenance, we receive the sign of the gift of God's own self-giving in Jesus Christ. In receiving the bread and wine, we not only respond to this merciful grace, but properly partake of it. This is a participation which involves faith and thankfulness in the human heart. As the words of distribution in the Book of Common Prayer make clear, the Eucharist is an act of remembrance of the covenant of grace of God, in which the heart responds and participates in grateful faith to that which was achieved by God in salvation. The minister says as the communicants receive the bread and wine:

The body of our Lord Jesus Christ, which was given for you, preserve your body and soul to eternal life. Take and eat this in remembrance that Christ died for you, and feed on him in your heart by faith with thanksgiving.

The blood of our Lord Jesus Christ, which was shed for you, preserve your body and soul to eternal life. Drink this in remembrance that Christ's blood was shed for you, and be thankful.

\footnotetext{
${ }^{43}$ Calvin differentiates between forms of sacrifice, and speaks of Christian sacrifice in all forms of worship (including the eucharist) as a 'sacrifice of thanksgiving' or 'a sacrifice of praise and reverence'. This is contrasted to 'the sacrifice of expiation ... which is intended to appease God's wrath, to satisfy his judgment, and so to wash sins and cleanse them that the sinner, purged of their filth and restored to the purity of righteousness, may return into favour with God.' This latter form of sacrifice is that which is accomplished not in the church but singularly by Christ. The uniqueness of Christ's sacrifice is something Calvin is determined to emphasise: 'And it was done but once, because the effectiveness and force of that one sacrifice accomplished by Christ are eternal ...' Calvin, Institutes, IV.18.13 (1441-2).

${ }^{44}$ On the inter-relation of grace and gratitude in the eucharistic theology of John Calvin, see Brian A. Gerrish, Grace and Gratitude: The Eucharistic Theology of John Calvin (Minneapolis: Fortress, 1993).
} 
This euchartistic act is not separate from the ethical or the obedient participative response of the creature to grace. In being obedient to the dominical command to break bread and share wine until the Lord's coming, we come in communion with one another, sharing together in thankfulness as one undeserving receiver of grace passing a morsel of bread to another. In holy communion, by coming together in worship, in the words of Wainwright, 'we receive the self-giving love of God, and the test of our thankfulness is whether we reproduce that pattern of self-giving in our daily relationship with others. ${ }^{45}$ And in this we begin to know what it means to live in a covenant of gratitude for grace, living lives of free and thankful self-giving to God and to others, structuring our own being beyond its propensity to the cor incurvatum in se as we look both to God and to others around us and participate with gratitude in the gift that is both their lives.

\footnotetext{
${ }^{45}$ Wainwright, Doxology, 422.
} 